\title{
Density Separation, Storage, Shelf Life, and Sensory Evaluation of 'Fry' Muscadine Grapes
}

\author{
Teresa L. Walker, Justin R. Morris ${ }^{1}$, Renee T. Threlfall, and Gary L. Main \\ Institute of Food Science and Engineering, University of Arkansas, 2650 North \\ Young Avenue, Fayetteville, AR 72704 \\ Olusola Lamikanra \\ USDA/ARS Southern Regional Research Laboratory, P.O. Box 19687, New \\ Orleans, LA 70179
}

\section{Stephen Leong \\ Center for Viticulture Science and Small Farm Development, Florida A\&M University, 603 Farm, Tallahassee, FL 32307}

Additional index words. Vitis rotundifolia, maturity, packaging

\begin{abstract}
Muscadine grapes (Vitis rotundifolia Michx.), native to the southeastern United States, have a distinct flavor, and grocers are interested in marketing them as table grapes. Two studies using 'Fry' muscadines were conducted to assist the muscadine industry in providing quality table grapes. Study 1 (1998 and 1999) evaluated density sorting and relationships between maturity, color, soluble solids, firmness, shelf life, and sensory evaluation of grapes. Study 2 (1998) determined the effect of storage on quality attributes of different maturities of grapes and evaluated use of polyethylene bags to extend their storage. Density separation successfully sorted grapes by maturity. Muscadine berry color may allow for visual or electronic sorting to eliminate immature fruit. Sensory panelists could distinguish differences in maturities for all sensory attributes. In 1999 maturities 3 and $4(\approx 24-33$ soluble solids : acid ratio) were preferred overall by panelists. As maturity increased, soluble solids and $\mathrm{pH}$ increased, and acidity decreased. Firmness decreased as maturity and storage at $2^{\circ} \mathrm{C}$ increased. Percent decay increased with maturity and storage time. Grapes stored in polyethylene bags had reduced decay. A chart developed from the 1999 data related berry color to soluble solids : acid ratio, soluble solids, tartaric acid, and pH. Data from these studies can be used by industry to establish harvest parameters and enhance marketability of 'Fry' muscadine grapes.
\end{abstract}

Muscadine grapes, native to the southeastern United States, have a distinctive flavor and are used for fresh market or for wines, juices, jams, and jellies. Muscadines grow in regions where temperatures remain above $-12{ }^{\circ} \mathrm{C}$. This growing area includes the southern region from eastern North Carolina to western Oklahoma (Morris, 1995). 'Fry' muscadine grapes are bronze-colored, large fruit with small clusters (Ferree, 1974). Grocers are interested in marketing muscadines as table grapes, but unlike Vitis vinifera table grapes, muscadines grow singly or as loose clusters and must be harvested as individual berries (Ballinger and McClure, 1983). A short shelf life and uneven ripening rates must also be overcome before muscadines can succeed in this highly competitive commercial market.

\footnotetext{
Received for publication 31 Oct. 2000. Accepted for publication $10 \mathrm{Feb}$. 2001. Published with the approval of the Director, Arkansas Agricultural Experiment Station. The cost of publishing this paper was defrayed in part by the payment of page charges. Under postal regulations, this paper therefore must be hereby marked advertisement solely to indicate this fact.

${ }^{1}$ To whom reprint requests should be addressed. Telephone: 501.575.4040; fax: 501.575.2165; e-mail address: jumorris@uark.edu
}

boxed in a polyethylene liner as compared to fruit boxed without a polyethylene liner. The unique attributes of muscadine grapes require particular care in evaluating the effectiveness of harvesting, sorting, packaging in polyethylene bags, and storage techniques. The objectives of Study 1 (1998 and 1999) were to evaluate the effectiveness of density sorting and to study the relationships among maturity, color, chemistry, sensory evaluation, and shelf life of 'Fry' muscadine grapes. The objectives of Study 2 (1998) were to determine the effect of storage time on the quality of different maturities of 'Fry' muscadine grapes and to evaluate use of polyethylene bags to extend storage of a commercial shipment of 'Fry' muscadine grapes.

\section{Materials and Methods}

Harvest and transport. In mid-August, hand-harvested 'Fry' muscadine grapes were selected at random from commercial shipments of muscadines at the Center for Viticulture Science and Small Farm Development, Florida Agricultural and Mechanical Univ., Tallahassee. Grapes were purchased from Georgia and Florida in 1998 and 1999, respectively. The grapes were transported in an air-conditioned van overnight to the Univ. of Arkansas, Fayetteville. The grapes were shipped in standard 10-kg vented boxes, the typical method used to transport muscadines to grocers. Grapes were immediately stored at $2{ }^{\circ} \mathrm{C}$.

Density separation. Uniform berries were density sorted (Lanier and Morris, 1979). Brine solutions of food-grade sodium chloride and water were prepared using specific gravity measurements determined by hydrometer and conversion tables (Wolf et al., 1980). Five density levels were prepared. Fruit were poured into the lowest percent brine solution, and the fruit that floated were removed and classified as the lowest maturity grade. The fruit that sank to the bottom were removed and placed in the next density level of sodium chloride solution. The procedure was repeated for the remaining solutions. All fruit that floated in the final brine solution were designated as the highest maturity grade. Density-sorted fruit were rinsed twice with water, and severely split and decayed fruit were removed. All fruit were weighed, and the percentage of fruit in each maturity grade were recorded.

Containers and packaging. For storage and packaging studies, muscadines were packed in clear, vented, pint-sized, clamshell containers (Fabri-Kal Corp., Kalamazoo, Mich.). Each container held $\approx 40$ muscadine grapes $(335 \mathrm{~g})$. Muscadines were weighed into clamshell containers using a PE-3600 DeltaRange top-loading balance (Mettler Instrument Corp., Highslow, N.J.).

Muscadines in clamshell containers were placed into polyethylene bags. The bags were a $0.03-\mathrm{mm}$ multilayered polyolefin (PD961EZ) bag (Cryovac, Duncan, S.C.). The manufacturer's technical data included a $\mathrm{O}_{2}$ transmission rate of $6000-8000 \mathrm{cc} \cdot \mathrm{m}^{-2}$ per 24 $\mathrm{h}$ and $\mathrm{CO}_{2}$ transmission rate of 19,000 
$22,000 \mathrm{cc} \cdot \mathrm{m}^{-2}$ per $24 \mathrm{~h}$. The bags had a surface area of $468 \mathrm{~cm}^{2}$. Bags were sealed using a PAC Vacuum Impulse Sealer PVS-GA18 (PAC, San Rafael, Calif.).

A Fisher-Hamilton Gas Partitioner was used to measure the equilibrated levels of $\mathrm{CO}_{2}$ and $\mathrm{O}_{2}$ within the sealed polyethylene bag after 1 week of storage at $2{ }^{\circ} \mathrm{C}$. The samples were done in duplicate. The partitioner was equipped with a $1.98 \mathrm{~m} \times 47.6 \mathrm{~mm}$ aluminumpacked column with 40-60 mesh molecular sieve $13 \times$ and a thermal conductivity cell detector with four tungsten filaments. The equilibrated levels of $\mathrm{CO}_{2}$ and $\mathrm{O}_{2}$ were determined to provide a general estimation of the atmosphere in the bags.

Storage conditions. The storage at $2{ }^{\circ} \mathrm{C}$ was in a temperature-controlled cold room with an average relative humidity of $89 \%$. The storage at $22{ }^{\circ} \mathrm{C}$ was in a temperature-controlled storage room with an average relative humidity of $30 \%$.

\section{Analyses}

$p H$, titratable acidity, and soluble solids. An automated titrimeter and electrode standardized to $\mathrm{pH} 4.00$ and $\mathrm{pH} 7.00$ buffers were used to measure $\mathrm{pH}$ and titratable acidity of extracted juice. Titratable acidity was determined by titration with $0.1 \mathrm{~N}$ sodium hydroxide to an endpoint of $\mathrm{pH}$ 8.2. The results of titratable acidity were reported as the percentage of tartaric acid. Soluble solids were measured using a Bausch and Lomb Abbe Mark II refractometer (Scientific Instruments, Keene, N.H.). Soluble solids, $\mathrm{pH}$, and titratable acidity were measured using juice from berries homogenized in a blender for $\approx 1 \mathrm{~min}$. Berries from the clamshell containers were homogenized to aid in the extraction of components from the skins and seeds and provide a representative sample. In some experiments, soluble solids of juice extracted from one-half of each sliced berry were measured.

Firmness. Firmness (maximum force to penetrate skin tissue) was determined by using one-half of a sliced berry. A TA-XT2 Texture Analyzer (Stable Micro Systems, Haslemere, England) equipped with a 2-mm-diameter probe penetrated the skin and mesocarp tissues $10 \mathrm{~mm}$ into the fruit at a rate of $10 \mathrm{~mm} \cdot \mathrm{s}^{-1}$. Data were analyzed using Texture Expert Version 1.17 , and measurements were expressed as force in Newtons (N) (Texture Technologies Corp., Scarsdale, N.Y.).

Color. Exterior skin berry color measurements were determined by using a black plate with a $23-\mathrm{mm}$ opening in the center. Individual, whole berries were placed in the opening of the plate, and berry color was analyzed using a Colorgard System/05 (BYK Gardner, Columbia, Md.). The system was standardized to a white plate with values " $L "=94.12$; "a" = -0.97; and "b" = -0.40. The CIE "L" value indicates how light or dark the juice is, with $0=$ black and $100=$ white. Hue angle describes color in angles from 0 to $360^{\circ}: 0=$ red; $90^{\circ}=$ yellow; $180^{\circ}=$ green $; 270^{\circ}=$ blue; and $360^{\circ}=$ back to red. Chroma is the aspect of color by which a sample appears to differ from gray of the same lightness and corresponds to intensity of the perceived color.

Decay and shelf life. Decay was evaluated by counting the number of decayed fruit (rotten or molded fruit) in each clamshell container. The percentage of decay was based on the total number of fruit in the clamshell container. Fruit were transferred from storage at 2 ${ }^{\circ} \mathrm{C}$ and to evaluate shelf life quality changes after 1 week at $22^{\circ} \mathrm{C}$.

\section{Treatments and Experimental Designs}

Study 1 (1998 and 1999). Effect of density sorting and the relationship among maturity, color, chemistry, and sensory characteristics of 'Fry' muscadine grapes.

Experiment 1 (density separation). Density levels $9.0 \%, 9.5 \%, 10.0 \%, 10.5 \%$, and $11.0 \%$ sodium chloride were used in 1998. Density levels $8.0 \%, 9.0 \%, 10.0 \%, 11.0 \%$, and $12.0 \%$ sodium chloride were used in 1999. The weight of muscadines in each maturity level was recorded to determine the percentage of fruit in each density level. Statistical analysis was not performed on this experiment. Data were collected to provide general information on the percentage of fruit of each density level in a commercial shipment.

Experiment 2 (chemical and color analysis). After density separation whole berries were numbered and analyzed for color. Twenty berries for each of the maturity levels were randomly selected for evaluation. Berries were halved; the juice from one berry half was used to measure soluble solids, and the other berry half was used to measure firmness. The experimental design consisted of maturity levels $(1,2,3,4$, and 5) and 20 replications. The variability from the experiment comes from the individual whole berries sampled. In 1999 a color chart was developed relating color to the chemistry (soluble solids: acid ratio, soluble solids, titratable acidity, and $\mathrm{pH}$ ) of the berry.

Experiment 3 (sensory analysis). Sensory analysis was conducted on initial quality. In 1998 and 1999, 30 panelists were given berries from each maturity level and ranked sensory characteristics. The ranking test is an extension of the paired comparison test, in which the panelist ranks the samples for intensity of a specific characteristic (Poste et al., 1991). If the panelist were asked to rank sweetness, the sweetest sample is ranked first; the second sweetest, second; the third sweetest, third; and the least sweet, fourth. Because samples were evaluated only in relationship to each other, results from one set of rankings can not be compared with the results from another set of rankings unless both contain the same samples. Samples were presented to panelists at room temperature in $60-\mathrm{mL}$ clear plastic soufflé cups with lids. The sample containers were labeled with three-digit random code numbers to eliminate individual bias. The results of the ranking test were checked for significance using the Friedman test for ranked data (Poste et al., 1991).

In 1998, the panelists ranked whole berry samples for firmness and sliced berries for sweetness and sourness. Panelists evaluated samples individually in partitioned areas under red lighting.

The sensory analysis was modified in 1999 to provide additional quality information. Panelists ranked whole berry samples for firmness and color and sliced berries for sweetness, muscadine flavor, and overall preference. Maturity 5 was excluded from the sensory analysis because of limited numbers of fruit. Panelists evaluated samples individually in partitioned areas under white lighting.

Experiment 4 (shelf life). In 1999, percent shelf life decay was determined by placing the unwrapped clamshell containers of each maturity level at $22{ }^{\circ} \mathrm{C}$ and evaluating percent decay after 7 and $10 \mathrm{~d}$. The experimental design was a $4 \times 2$ factorial consisting of maturities (1,2,3, and 4$)$, shelf life time ( 7 and $10 \mathrm{~d})$, and three replications. A clamshell container of muscadine berries was used as a replication.

\section{Study 2 (1998)}

Experiment 1 (storage of different maturities). Fruit from maturity levels 1-5 were placed in clamshell containers and each clamshell was sealed in a polyethylene bag. Whole berries were blended and evaluated for $\mathrm{pH}$, titratable acidity, and soluble solids at 0,2 ,

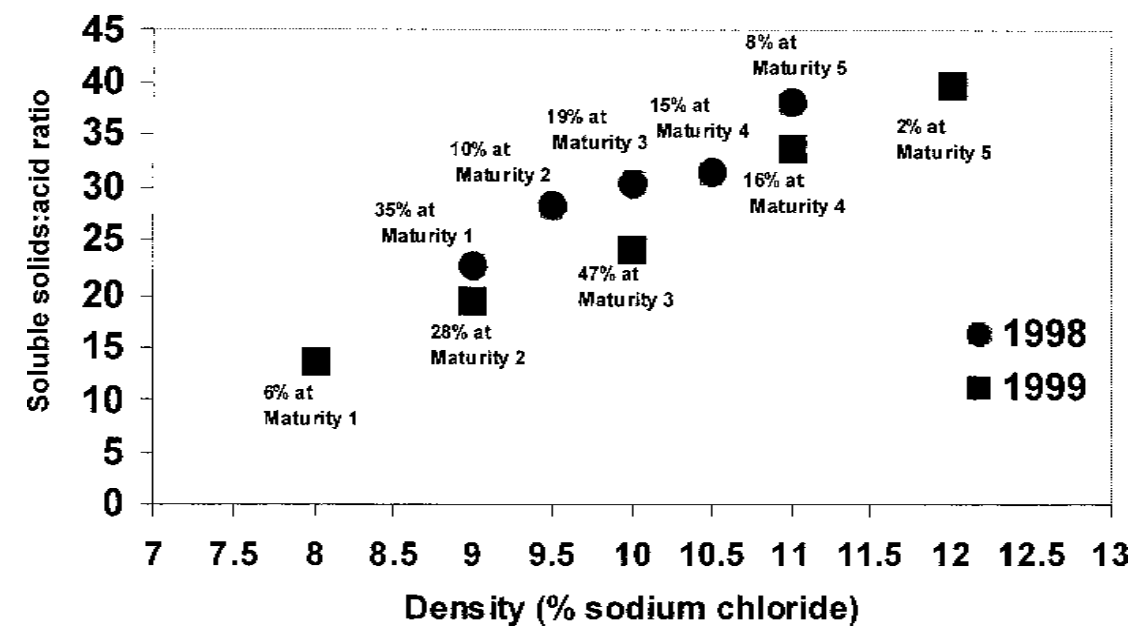

Fig. 1. Soluble solids : acid ratio and the percentage of fruit of the different maturity levels of density-sorted 'Fry' muscadine grapes from different commercial vineyards for 1998 and 1999. 
Table 1. Soluble solids content and color quality of whole, density-sorted 'Fry' muscadine grapes (1998).

\begin{tabular}{lcccccc}
\hline \hline $\begin{array}{l}\text { Maturity } \\
\text { level }\end{array}$ & $\begin{array}{c}\text { Soluble } \\
\text { solids }(\%)\end{array}$ & CIE “L” & CIE “a" & CIE "b" & $\begin{array}{c}\text { Hue angle } \\
\left(\mathrm{b} / \mathrm{a} \tan ^{-1}\right)\end{array}$ & $\begin{array}{c}\text { Chroma } \\
\left(\mathrm{a}^{2}+\mathrm{b}^{2}\right)^{1 / 2}\end{array}$ \\
\hline 1 & $16.3 \mathrm{e}^{2}$ & $31.1 \mathrm{~b}$ & $-0.70 \mathrm{c}$ & $14.0 \mathrm{a}$ & $90.7 \mathrm{a}$ & $14.2 \mathrm{a}$ \\
2 & $17.1 \mathrm{~d}$ & $33.4 \mathrm{a}$ & $-0.04 \mathrm{bc}$ & $12.7 \mathrm{~b}$ & $89.3 \mathrm{a}$ & $12.9 \mathrm{~b}$ \\
3 & $17.6 \mathrm{c}$ & $31.1 \mathrm{~b}$ & $0.49 \mathrm{~b}$ & $12.2 \mathrm{~b}$ & $85.9 \mathrm{~b}$ & $12.4 \mathrm{~b}$ \\
4 & $18.5 \mathrm{~b}$ & $31.3 \mathrm{ab}$ & $1.24 \mathrm{a}$ & $11.9 \mathrm{~b}$ & $83.1 \mathrm{bc}$ & $12.1 \mathrm{~b}$ \\
5 & $21.1 \mathrm{a}$ & $32.1 \mathrm{ab}$ & $1.85 \mathrm{a}$ & $12.9 \mathrm{~b}$ & $80.9 \mathrm{c}$ & $13.2 \mathrm{ab}$ \\
\hline
\end{tabular}

${ }^{2}$ Means separated within columns by LSD, $P \leq 0.05$.

4 , and 6 weeks of storage at $2{ }^{\circ} \mathrm{C}$. Whole, sliced berries were used to evaluate firmness during storage. The experimental design was a $5 \times 4$ factorial consisting of maturity $(1,2,3,4$, and $5)$, storage time $(0,2,4$, and 6 weeks), and three replications. A clamshell container of muscadine berries was used as a replication.

Experiment 2 (polyethylene wrap of commercial shipment). Fruit from maturities 1,2, and 3 were combined and used for this study to simulate a commercial sample. The fruit were placed in clamshell containers that were either wrapped or nonwrapped with a polyethylene bag and stored 6 weeks at $2{ }^{\circ} \mathrm{C}$. Objective evaluations were conducted as discussed in Study 2 . The experimental design was a $4 \times 2$ factorial consisting of storage time $(0,2,4$, and 6 weeks), polyethylene wrap (no wrap and wrap), and three replications. A clamshell container of muscadine berries was used as a replication

Statistical analysis. Sensory data were analyzed for significance using the Friedman test for ranked data (Poste et al., 1991). Objective data were analyzed using General Linear Model Procedure for Statistical Analysis System, Cary, N.C. (SAS, 1985). Multiple comparisons among treatments were made using the $5 \%$ least significant difference.

\section{Results and Discussion}

\section{Studies}

\section{Study 1}

Experiment 1 (density separation). Density separation successfully sorted muscadines into maturity levels. Riper fruit required a higher density salt solution for separation. The maturity levels were assigned based on density levels required for separation. After density separation, fruit in each maturity level were weighed to calculate percent fruit (Fig. $1)$.

These data provide insight into the distribution of fruit in commercial shipments from different locations each year. The 1998 harvest had a tight range of maturities with a high

Table 2. Sensory rankings for firmness, sweetness, and sourness of 'Fry' muscadine grapes (1998).

\begin{tabular}{lccc}
\hline Maturity & Firmness & Sweetness & Sourness \\
\hline 1 & $56 \mathrm{~b}^{\mathrm{z}}$ & $123 \mathrm{a}$ & $68 \mathrm{bc}$ \\
2 & $90 \mathrm{a}$ & $92 \mathrm{ab}$ & $98 \mathrm{ab}$ \\
3 & $103 \mathrm{a}$ & $63 \mathrm{~b}$ & $114 \mathrm{a}$ \\
4 & $91 \mathrm{a}$ & $102 \mathrm{a}$ & $66 \mathrm{c}$ \\
5 & $114 \mathrm{a}$ & $70 \mathrm{~b}$ & $104 \mathrm{a}$
\end{tabular}

${ }^{\mathrm{z}}$ Any two rank sums within a column not followed by the same letter are significantly different at $P \leq$ 0.05 . Low rank sum values indicate the most firm, sweet, and sour fruit. by maturity. Ballinger et al. (1978) found that ripeness, as determined by light-sorting tech-

${ }^{\mathrm{z}}$ Means separated within columns by LSD, $P \leq 0.05$.

${ }^{\text {ss Nonsignificant. }}$ niques, correlated well with the soluble solids and titratable acidity ratios. Mechanical sorting may be more valuable than density sorting in small, fresh-market operations that are not equipped to remove the excess moisture resulting from the density-sorting procedure.

Experiment 3 (sensory analysis). Sensory analysis was conducted on initial quality since previous research indicated that flavor decreased only slightly during storage of sound fruit (James et al., 1999) (Table 2). Maturity 1 was more firm than all other maturities (Table 2). Panelists could not detect a significant difference in firmness among maturities 2-5. Maturity 1 was more firm, less sweet, and more sour; whereas maturity 5 was less firm, more sweet, and less sour. Panelists had difficulty ranking sweetness and sourness for maturities $2-5$, which may be the result of the tight range of maturities (Fig. 1).

Maturity 3 had a soluble solids : acid ratio of 30.5 , which was the closest to the recommended optimum of 30 (Flora, 1979). In 1998, panelists ranked maturity 3 in the highest sweetness and the lowest sourness ranking. Maturity 2, with a soluble solids : acid ratio of 28.4 and maturity 4 at 31.5 , was within the acceptable range cited above.

\section{Study 2}

Experiment 1 (storage of different maturities). A storage study was established for each maturity level to investigate changes in soluble

Table 3. Quality of different maturities of density-sorted 'Fry' muscadine grapes stored at $2{ }^{\circ} \mathrm{C}$ (1998).

\begin{tabular}{|c|c|c|c|c|c|c|}
\hline $\begin{array}{l}\text { Main } \\
\text { effect }\end{array}$ & $\begin{array}{c}\text { Soluble } \\
\text { solids (SS) } \\
(\%)\end{array}$ & $\mathrm{pH}$ & $\begin{array}{c}\text { Titratable } \\
\text { acidity } \\
(\text { tartaric \%) }\end{array}$ & $\begin{array}{l}\text { Ripeness } \\
\text { indices } \\
\left(\mathrm{SS} \times \mathrm{pH}^{2}\right)\end{array}$ & $\begin{array}{c}\text { Decay } \\
(\%)\end{array}$ & $\begin{array}{c}\text { Firmness } \\
\text { (N) }\end{array}$ \\
\hline \multicolumn{7}{|l|}{ Maturity level } \\
\hline 1 & $14.2 \mathrm{e}^{\mathrm{z}}$ & 3.33 & 0.65 & $157.0 \mathrm{e}$ & 5.7 & $10.01 \mathrm{a}$ \\
\hline 2 & $15.2 \mathrm{~d}$ & 3.39 & 0.59 & $176.3 \mathrm{~d}$ & 13.4 & $9.51 \mathrm{ab}$ \\
\hline 3 & $15.8 \mathrm{c}$ & 3.41 & 0.57 & $183.8 \mathrm{c}$ & 22.4 & $9.16 \mathrm{~b}$ \\
\hline 4 & $17.0 \mathrm{~b}$ & 3.42 & 0.59 & $198.5 \mathrm{~b}$ & 31.5 & $8.88 \mathrm{~b}$ \\
\hline 5 & $19.5 \mathrm{a}$ & 3.46 & 0.58 & $233.8 \mathrm{a}$ & 37.9 & $7.97 \mathrm{c}$ \\
\hline \multicolumn{7}{|l|}{ Storage (weeks) } \\
\hline 0 & $17.09 \mathrm{a}$ & 3.41 & 0.57 & $199.7 \mathrm{a}$ & 0.0 & $10.35 \mathrm{a}$ \\
\hline 2 & $16.35 \mathrm{~b}$ & 3.41 & 0.57 & $191.0 \mathrm{~b}$ & 19.2 & $9.04 \mathrm{~b}$ \\
\hline 4 & $15.97 \mathrm{c}$ & 3.41 & 0.63 & $186.2 \mathrm{c}$ & 25.7 & $8.55 \mathrm{~b}$ \\
\hline 6 & $15.83 \mathrm{c}$ & 3.38 & 0.61 & $181.7 \mathrm{~d}$ & 42.4 & $8.47 \mathrm{~b}$ \\
\hline Maturity $\times$ storage & NS & 0.0032 & 0.0316 & 0.0017 & 0.0001 & NS \\
\hline
\end{tabular}

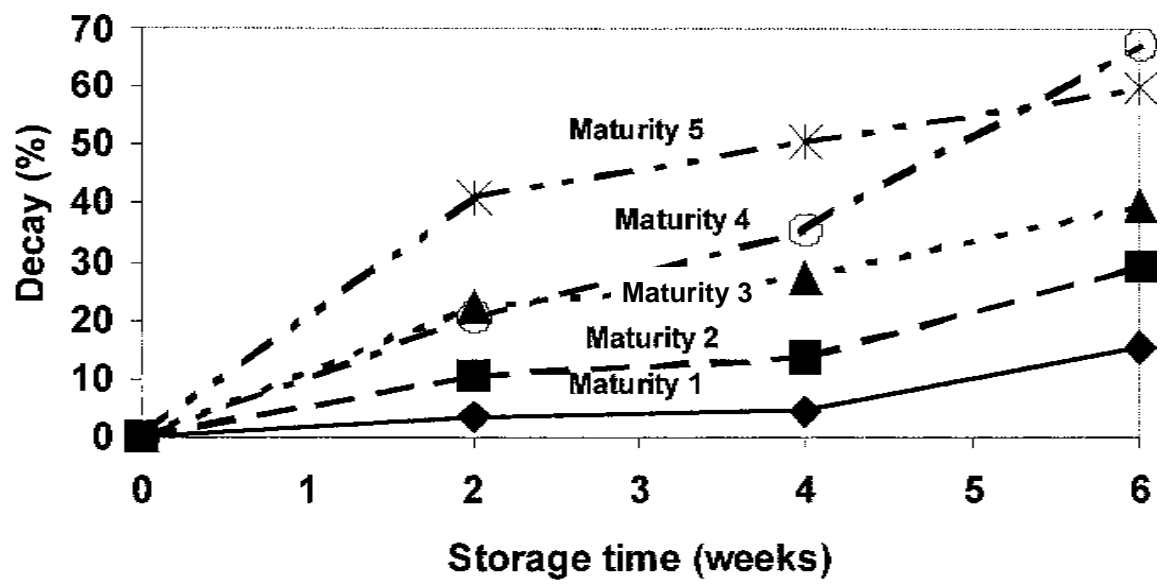

Fig. 2. Percent decay of maturity levels of density-sorted 'Fry' muscadine grapes in clamshell containers sealed with polyethylene bags during 6 weeks' storage at $2{ }^{\circ} \mathrm{C}(1998)$. 
Table 4. Decay, firmness, and weight loss of 'Fry' muscadine grapes packaged in clamshell containers, sealed in polyethylene bags, and stored at $2{ }^{\circ} \mathrm{C}(1998)$.

\begin{tabular}{lccc}
\hline \hline Main effects & $\begin{array}{c}\text { Decay } \\
(\%)\end{array}$ & $\begin{array}{c}\text { Firmness } \\
(\mathrm{N})\end{array}$ & $\begin{array}{c}\text { Wt loss } \\
(\mathrm{g})\end{array}$ \\
\hline Storage (weeks) & & & \\
0 & $0.0 \mathrm{c}^{2}$ & $11.4 \mathrm{a}$ & $0.0 \mathrm{c}$ \\
2 & $11.6 \mathrm{~b}$ & $10.5 \mathrm{~b}$ & $8.4 \mathrm{~b}$ \\
4 & $14.9 \mathrm{~b}$ & $9.8 \mathrm{bc}$ & $11.1 \mathrm{~b}$ \\
6 & $43.6 \mathrm{a}$ & $9.5 \mathrm{c}$ & $21.8 \mathrm{a}$ \\
$\quad \begin{array}{l}\text { Packaging } \\
\quad \text { No wrap }\end{array}$ & $21.1 \mathrm{a}$ & $10.8 \mathrm{a}$ & $21.8 \mathrm{a}$ \\
$\quad \begin{array}{l}\text { Polyethylene } \\
\quad \text { wrap }\end{array}$ & $14.0 \mathrm{~b}$ & $9.9 \mathrm{~b}$ & $-1.2 \mathrm{~b}$ \\
$\begin{array}{l}\text { Storage } \\
\quad \times \text { package }\end{array}$ & NS & NS & 0.0001 \\
\hline
\end{tabular}

${ }^{2}$ Means separated within columns by LSD, $P \leq 0.05$.

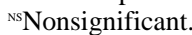

solids, $\mathrm{pH}$, titratable acidity, decay, and firmness during a 6-week storage period (Table 3). Since the interactions of maturity and storage were nonsignificant for soluble solids and firmness, the data are presented as the main effects of maturity and storage. As maturity level of the berries increased, soluble solids increased, and firmness decreased. As storage time increased, both soluble solids and firmness decreased.

In general, the ripeness indices increased as maturity increased, but decreased with increasing storage time. The interaction was caused by a slight increase in the index of maturity 1 at 2 weeks of storage. Soluble solids $\times \mathrm{pH}^{2}$ was a good indicator of harvest

Table 5. Soluble solids, color quality, and firmness of whole, density-sorted 'Fry' muscadine grapes (1999).

\begin{tabular}{lccccccc}
\hline $\begin{array}{l}\text { Maturity } \\
\text { level }\end{array}$ & $\begin{array}{c}\text { Soluble } \\
\text { solids (\%) }\end{array}$ & CIE "L" & CIE “a" & CIE "b" & $\begin{array}{c}\text { Hue angle } \\
\left(\mathrm{b} / \mathrm{a} \tan ^{-1}\right)\end{array}$ & $\begin{array}{c}\text { Chroma } \\
\left(\mathrm{a}^{2}+\mathrm{b}^{2}\right)^{1 / 2}\end{array}$ & $\begin{array}{c}\text { Firmness } \\
(\mathrm{N})\end{array}$ \\
\hline 1 & $12.9 \mathrm{~d}^{2}$ & $40.9 \mathrm{a}$ & $-6.2 \mathrm{~d}$ & $24.9 \mathrm{a}$ & $103.9 \mathrm{c}$ & $25.7 \mathrm{a}$ & $9.7 \mathrm{a}$ \\
2 & $15.2 \mathrm{c}$ & $40.9 \mathrm{a}$ & $-3.2 \mathrm{c}$ & $21.9 \mathrm{~b}$ & $98.2 \mathrm{c}$ & $22.2 \mathrm{~b}$ & $9.9 \mathrm{a}$ \\
3 & $16.7 \mathrm{~b}$ & $38.6 \mathrm{~b}$ & $-0.3 \mathrm{~b}$ & $20.1 \mathrm{c}$ & $234.7 \mathrm{~b}$ & $20.2 \mathrm{c}$ & $9.4 \mathrm{a}$ \\
4 & $19.3 \mathrm{a}$ & $36.3 \mathrm{c}$ & $3.9 \mathrm{a}$ & $17.8 \mathrm{~d}$ & $76.7 \mathrm{a}$ & $18.3 \mathrm{~d}$ & $7.7 \mathrm{~b}$ \\
5 & $19.7 \mathrm{a}$ & $33.7 \mathrm{~d}$ & $4.1 \mathrm{a}$ & $17.1 \mathrm{~d}$ & $76.5 \mathrm{a}$ & $17.7 \mathrm{~d}$ & $7.1 \mathrm{~b}$
\end{tabular}

${ }^{\mathrm{z}}$ Means separated within columns by LSD, $P \leq 0.05$.

quality for wine, with an optimal range of 200270 for vinifera wine grapes (Coombe et al., 1980). The acceptable range for 'Fry' muscadine grapes was 175-200 for fresh market.

Decay was affected by an interaction between maturity and storage, since maturity 4 had more decay than expected at 6 weeks of storage (Fig. 2). Percent decay increased with both maturity and storage time. However, maturity levels 3 and 4 showed only $10 \%$ decay after 1 week. Maturity 5, the ripest maturity, had $20 \%$ decay after 1 week. By the fourth week of storage, maturities 1,2 , and 3 had $<30 \%$ decay.

Experiment 2 (polyethylene wrap of commercial shipment). The decay, firmness, and weight change effects of wrapping the clamshell containers of muscadines with a polyethylene bag were studied. A random mixture of maturity levels 1,2 , and 3 was used to simulate a commercial sample. Equilibrated levels of $\mathrm{CO}_{2}$ and $\mathrm{O}_{2}$ in the sealed polyethylene bags were $3.9 \%$ and $10.1 \%$, respectively, after 1 week of storage at $2{ }^{\circ} \mathrm{C}$.

Since average of the maturity levels for each treatment were the same, differences in soluble solids, $\mathrm{pH}$, and acidity were not expected. As storage time increased, decay increased and firmness decreased. Grapes in clamshell containers wrapped in polyethylene bags had $\approx 30 \%$ less decay than grapes not wrapped in polyethylene bags, but were less firm than nonwrapped fruit (Table 4), possibly because of dehydration of grapes in the unwrapped packages.

Total weight loss of the berries in the clamshell containers was affected by an interaction between package and storage treatments. Weight loss was not only from dehydration by evaporation of the moisture from the berries, but also from loss of moisture from the cracked/ split berries, especially in the later storage times. The treatments sealed in the polyethylene bags resulted in a slight weight gain due to the accuracy of the scales. The interaction was caused by the weight gain since the moisture was contained within the polyethylene bag.

\section{Studies}

The fruit in the 1999 study had almost $63 \%$ of the fruit from maturity levels 3 and 4 (Fig. 
Table 6. Sensory ratings for firmness, sweetness, muscadine flavor, overall preference, and color of 'Fry' muscadine grapes (1999).

\begin{tabular}{lccccc}
\hline $\begin{array}{l}\text { Maturity } \\
\text { level }\end{array}$ & Firmness & Sweetness & $\begin{array}{c}\text { Muscadine } \\
\text { flavor }\end{array}$ & $\begin{array}{c}\text { Overall } \\
\text { preference }\end{array}$ & $\begin{array}{c}\text { Color } \\
\text { Green to bronze }\end{array}$ \\
\hline 1 & $39 \mathrm{c}^{2}$ & $112 \mathrm{a}$ & $107 \mathrm{a}$ & $110 \mathrm{a}$ & $32 \mathrm{c}$ \\
2 & $63 \mathrm{bc}$ & $89 \mathrm{a}$ & $92 \mathrm{ab}$ & $90 \mathrm{a}$ & $61 \mathrm{~b}$ \\
3 & $82 \mathrm{ab}$ & $63 \mathrm{~b}$ & $67 \mathrm{~b}$ & $58 \mathrm{~b}$ & $89 \mathrm{a}$ \\
4 & $106 \mathrm{a}$ & $36 \mathrm{c}$ & $34 \mathrm{c}$ & $42 \mathrm{~b}$ & $108 \mathrm{a}$
\end{tabular}

${ }^{\mathrm{z}}$ Any two rank sums within a column not followed by the same letter are significantly different at $P \leq 0.05$. Low rank sum values indicate more muscadine flavor, preference, and sweetness. Low rank sum values for firmness and color indicate firm, green fruit.

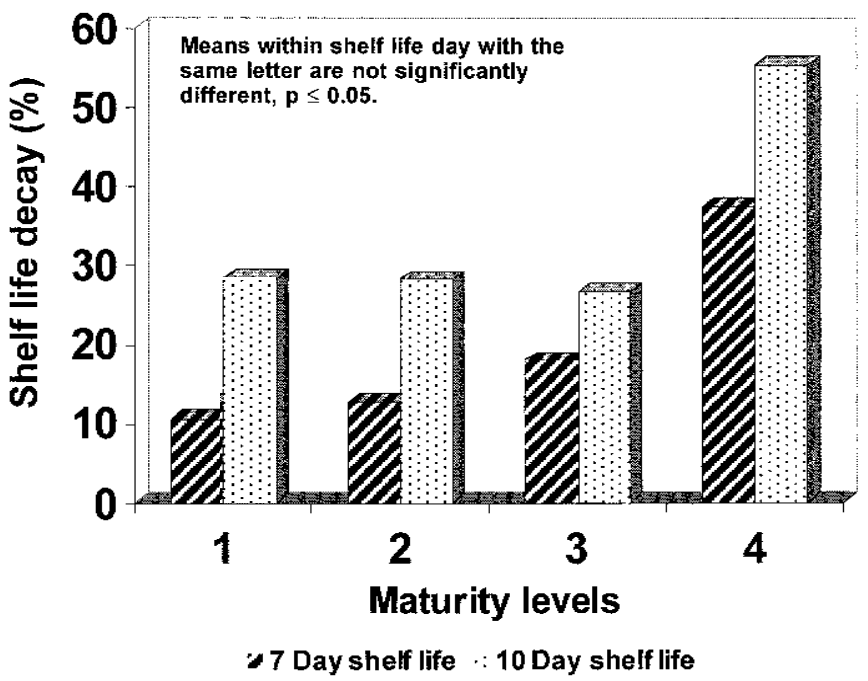

Fig. 4. Shelf life at $22{ }^{\circ} \mathrm{C}$ of different maturity levels of density-sorted 'Fry' muscadine grapes (1999) in clamshell containers.

1). The fruit in the 1998 study had a high percentage $(35 \%)$ of fruit with a low sweetness ranking (maturity 1) as determined by the sensory panel.

The soluble solids and maturity level experiments were repeated but included firmness. Similar trends of increasing soluble solids and a color shift with increasing maturity resulted (Table 5). Density-sorted maturities were correlated with soluble solids of the 'Fry' muscadine grapes $\left(\mathrm{r}^{2}=0.87\right)$.

A color chart was developed from the 1999 data showing that an increase in bronze color correlates with an increase in soluble solids : acid ratio, soluble solids, and $\mathrm{pH}$ and a decrease in titratable acidity (Fig. 3). Figure 3 illustrates the extremes in color and fruit chemistry of handpicked fruit from a given harvest date. The relationships between color and fruit chemistry may vary with vineyard and with season; however, this color chart can serve as a rough guide for relating bronze coloration to harvest parameters in 'Fry' muscadines.

As in 1998, trends for decreasing firmness and increasing sweetness with increasing maturity were detected in 1999 (Table 6). Panelists were able to distinguish both visual color and sensory characteristics. Bronze color and muscadine flavor increased with maturity.
Maturity levels 3 and 4 were preferred significantly over levels 1 and 2. Maturities 3 and 4 had soluble solids : acid ratios of 24.1 and 33.7 , respectively, and were closest to the accepted range of 25-35 (Flora, 1979). Overall preference and sweetness rankings by the panelists were related to the soluble solids : acid ratio analysis.

The shelf life study of maturities performed on muscadine grapes in unwrapped clamshell containers indicated that fruit at maturity 3 had $<20 \%$ decay in clamshell containers at room temperature for $7 \mathrm{~d}$ (Fig. 4).

\section{Conclusions}

Density separation separated 'Fry' muscadines into different maturities, but objective and sensory measurements indicated that the berries could also be separated by color. The maturity of muscadines could be distinguished by other factors, such as soluble solids : acid ratio, soluble solids, titratable acidity, and $\mathrm{pH}$. Increasing sweetness in sensory analysis corresponded to chemical trends, such as increasing soluble solids : acid ratio with increasing maturity. In both years, sensory panelists could distinguish maturity differences in the sensory attributes. In 1999, sensory data showed that panelists preferred overall maturity levels 3 and 4.

The delicate nature of muscadines, especially at the higher maturities, has prompted growers to harvest muscadines at lower maturity levels to increase storage time. However, berries wrapped in polyethylene bags can be stored longer with less decay. With two consecutive years and two commercial suppliers, the percentage of grapes that was most marketable varied greatly due to differences in the distributions of maturity levels. The color chart developed could help the 'Fry' muscadine industry to establish harvest parameters. Furthermore, similar research could provide visual and chemical standards for other cultivars of muscadines.

\section{Literature Cited}

Ballinger, W.E. and W.F. McClure. 1983. The effect of ripeness on storage quality of 'Carlos' muscadine grapes. Scientia Hort. 18:241-245.

Ballinger, W.E., W.F. McClure, W.B. Nesbitt, and E.P. Maness. 1978. Light-sorting muscadine grapes (Vitis rotundifolia Michx.) for ripeness. J. Amer. Soc. Hort. Sci. 103:629-634.

Coombe, B.G., R.J. Dundon, and A.W.S. Short. 1980. Indices of sugar-acidity as ripeness criteria for wine grapes. J. Sci. Food Agr. 31:495502.

Drake, S.R., E.M. Kupferman, and J.K. Fellman. 1988. 'Bing' sweet cherry (Prunus avium L.) quality as influenced by wax coating and storage temperature. J. Food Sci. 53:124-126,156.

Du Plessis, C.S. 1984. Optimum maturity and quality parameters in grapes: A review. S. Afr. J. Enol. Viticult. 5:35-42.

Flora, L.F. 1979. Optimum quality parameters of muscadine grape juices, beverages, and blends. J. Food Qual. 2:219-229.

Ferree, M.E. 1974. Muscadine grape culture. Coop. Ext. Serv., Univ. of Georgia, College of Agr., Athens. Bul. 739.

James, J.A., O. Lamikanra, G. Dixon, J. Morris, G. Main, T. Walker, and J. Silva. 1999. Interstate shipment and storage of fresh muscadine grapes. J. Food Qual. 22:605-617.

Kattan, A.A., C.Q. Sharp, and J.R. Morris. 1969. A mechanical sorter for tomatoes. Ark. Farm Res. 18:8.

Lanier, M.R. and J.R. Morris. 1979. Evaluation of density separation for defining fruit maturities and maturation rates of once-over harvested muscadine grapes. J. Amer. Soc. Hort. Sci. 104:249-252.

Morris, J.R. 1995. Grape growing, p. 463-505. In: N.F. Childers, J.R. Morris, and G.S. Sibbett (eds.). Modern fruit science. Hort. Publ., Florida.

Poste, L.M., D.A. Mackie, G. Butler, and E. Larmond. 1991. Laboratory methods for sensory analysis of food. Res. Branch Agr. Can. Publ. 1864/E.

SAS Institute Inc. 1985. SAS user's guide statistics, 5th ed. SAS Inst., Cary, N.C.

Wolf, A.V., M.G. Brown, and P.G. Prentiss. 1980. Concentration properties of aqueous solutions: Conversion tables, p. D-229-276. In: R.C. Weast (ed.). CRC handbook of chemistry and physics. CRC Press, Florida. 